\title{
ANALISIS HUJAN LEBAT TANGGAL 27 SEPTEMBER 2017 DI DKI JAKARTA
}

\author{
Analysis of Heavy Rain Event on 27 September 2017 \\ in Jakarta Area.
}

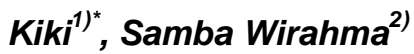 \\ ${ }^{1)}$ Pusat Meteorologi Publik, Badan Meteorologi, Klimatologi dan Geofisika (BMKG), Jl. Angkasa I No.2 \\ Kemayoran, Jakarta Pusat, DKI Jakarta \\ 2) Balai Besar Teknologi Modifikasi Cuaca - Badan Pengkajian dan Penerapan Teknologi, Gedung Ir. \\ Mohammad Soebagio, GEOSTECH (820), Kawasan PUSPIPTEK, Serpong, Tangerang Selatan \\ *E-mail : kiki.ekasiwi@bmkg.go.id
}

\begin{abstract}
Intisari
Pada 27 September 2017 beberapa wilayah di DKI Jakarta dilanda hujan dengan intensitas lebat yang memicu genangan di beberapa wilayah. Wilayah DKI Jakarta pada bulan September masih dalam periode transisi dari musim kemarau menuju musim hujan, sehingga potensi kejadian hujan dengan intensitas ringan hingga lebat yang disertai kilat/petir dan angin kencang cukup tinggi, meski umumnya masih bersifat sporadis. Dengan menggunakan data reanalysis model diketahui bahwa pada saat kejadian terdapat anomali pola angin di lapisan $850 \mathrm{hPa}$ dibandingkan dengan klimatologisnya, serta didentifikasi adanya anomali kelembapan udara di lapisan bawah hingga $500 \mathrm{hPa}$ yang lebih basah dibandingkan dengan klimatologisnya. Pertumbuhan awan hujan tipe Nimbustratus yang optimal pada saat kejadian dipicu oleh daerah konvergensi yang terbentuk di wilayah Banten, DKI Jakarta, hingga Jawa Barat, serta kondisi atmosfer yang basah hingga di lapisan menengah.
\end{abstract}

Kata Kunci : Hujan Lebat, Konvergensi, Belokan Angin, Genangan.

\begin{abstract}
On September 27, 2017, several areas in DKI Jakarta were surge by heavy rain that triggered inundations in some areas. DKI Jakarta area in September is still in the transition period from the dry season to the rainy season, so the potential for the occurance of rain with mild to light intensity accompanied by thunder/lightning and strong winds is still quite high, although generally still sporadic. Using the reanalysis data model it is known that at the time of the event there was wind pattern anomaly in layer $850 \mathrm{hPa}$ compared with its climatology, and also been identified an anomaly of air humidity in the lower layer of the atmosphere up to $500 \mathrm{hPa}$ wetter than its climatology. The optimum growth of Nimbustratus cloud at the time of the incident was triggered by the convergence area formed in Banten, DKI Jakarta, and West Java, as well as the wet atmospheric conditions up to the middle layer.
\end{abstract}

Keywords : Heavy Rainfall, Convergence, Shearline, Inundations.

\section{PENDAHULUAN}

Banjir adalah salah satu permasalahan di kota DKI Jakarta yang sampai saat ini masih belum dapat diselesaikan. Beberapa kasus terburuk dari kejadian banjir di DKI Jakarta, yaitu pada tahun 1996 dan 2002. Hal tersebut terjadi kembali pada 2 Februari 2007 dimana banjir besar terulang, yang diakibatkan oleh besarnya curah hujan di wilayah Jakarta Barat, Jakarta Pusat dan Jakarta Utara (Gernowo \& Yulianto, 2010).

Historis banjir DKI Jakarta dari catatan sejarah perkembangan kota, banjir besar dimulai tahun 1621, 1654, 1918, 1976, 1996, 2002 dan 2007 (BPBD, 2013). Kombinasi simultan fenomena angin lokal, seruakan dingin, fase basah MJO dan pusaran di wilayah barat daya Jawa menyebabkan fenomena banjir di Jakarta pada awal Februari 2002, 2007 dan 2008 (Aldrian, 2008).

Hujan ekstrem di DKI Jakarta merupakan salah satu penyebab utama banjir, bahkan pada penelitian yang dilakukan oleh Siswanto et al. (2017), pengamatan peristiwa curah hujan dua hari pada bulan Februari 2015 sangat luar biasa dengan jumlah akumulasi tertinggi yang diamati yaitu $455 \mathrm{~mm}$ dan tertinggi sejak awal abad ke20.

Berdasarkan proyeksi hujan ekstrem yang dilakukan menggunakan LARS WG diperoleh hasil probabilitas banjir akibat hujan ekstrem 
tertinggi terdapat pada periode kedua yaitu tahun 2016 hingga tahun 2020 (Utomo, 2012).

Pada 27 September 2017 lalu wilayah DKI Jakarta diguyur hujan intensitas lebat yang memicu terjadinya genangan di beberapa wilayah, berdasarkan data rekapitulasi kejadian cuaca ekstrem dari Pusat Meteorologi Publik BMKG Jakarta, kejadian hujan ekstrem di wilayah DKI Jakarta pada tanggal 27 September 2017 lalu merupakan kejadian kedua sepanjang bulan tersebut, hujan lebat yang memicu genangan di wilayah DKI Jakarta juga terjadi pada tanggal 10 September 2017. Selain di DKI Jakarta, pada bulan September 2017 lalu tercatat sebanyak 6 kejadian banjir dan tanah longsor yang dipicu oleh hujan intensitas tinggi di beberapa wilayah lain di Indonesia seperti, Palangkaraya, Ambon, Pontianak, dan Padang.

Berdasarkan Prakiraan Musim Hujan 2017/2018 yang telah dirilis oleh BMKG awal bulan lalu, diketahui bahwa onset musim hujan di wilayah DKI Jakarta bersifat Normal, yaitu antara dasarian III Oktober 2017 hingga dasarian II November 2017 untuk wilayah Jakarta Selatan dan Jakarta Timur bagian selatan, serta antara dasarian I hingga dasarian III Desember 2017 untuk wilayah DKI Jakarta lainnya, seperti ditampilkan pada gambar 1 berikut ini.

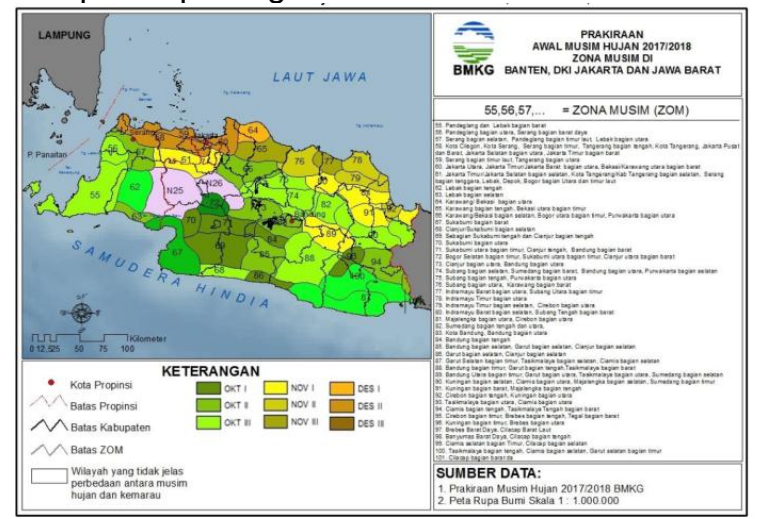

Gambar 1. Prakiraan awal musim hujan

2017/2018 ZOM di Banten, DKI Jakarta, dan Jawa Barat. (Sumber : BMKG)

Sehingga berdasarkan prakiraan musim hujan tersebut, wilayah DKI Jakarta pada saat ini umumnya masih dalam periode musim transisi dari musim kemarau menuju musim penghujan. Dimana diketahui bahwa pada musim transisi ini hujan yang banyak terjadi adalah hujan yang dihasilkan oleh awan - awan konvektif seperti Cumulonimbus, yang umumnya memiliki intensitas sedang hingga lebat yang disertai kilat/petir serta angin kencang berdurasi singkat.

\section{METODE}

Data yang digunakan dalam kajian ini adalah sebagai berikut :

1. Data curah hujan harian Stasiun BMKG, ARG, AWS dan Pos Hujan Kerjasama wilayah DKI
Jakarta tanggal 26, 27 dan 28 September 2017.

2. Data reanalysis model WRF resolusi spasial $27 \mathrm{~km}$, hasil running Pusat Meteorologi Publik BMKG Jakarta yang dilakukan per 12 jam, yaitu jam 07,00 WIB dan 19.00 WIB.

3. Citra Himawari-8 per jam tanggal 27 September 2017.

4. Produk citra radar cuaca site Tangerang, Banten tanggal 26 dan 27 September 2017.

Metode yang digunakan dalam kajian ini merupakan perpaduan antara metode studi kasus dan metode deskriptif. Software yang digunakan dalam pengolahan data penginderaan jauh diantaranya adalah Sataid untuk data citra satelit cuaca serta aplikasi Rainbow untuk visualisasi produk citra radar cuaca.

\section{HASIL DAN PEMBAHASAN}

Analisis yang dilakukan untuk kejadian hujan lebat ini adalah rekapitulasi curah hujan harian dari Stasiun BMKG, ARG, serta pos pengamatan hujan BMKG di wilayah DKI Jakarta, analisis dinamika atmosfer, analisis citra satelit cuaca serta analisis citra radar cuaca pada saat kejadian hujan lebat.

\subsection{Rekapitulasi Akumulasi Curah Hujan Harian}

Berdasarkan data curah hujan harian dari beberapa titik pengamatan di DKI Jakarta diketahui bahwa hujan yang terjadi pada tanggal 27 September 2017 berada pada kisaran intensitas ringan-lebat, informasi ini ditampilkan pada tabel 1 berikut.

Tabel 1. Akumulasi Curah Hujan Harian dalam Satuan Milimeter

\begin{tabular}{|c|c|c|c|}
\hline Stasiun & $\begin{array}{l}26 \text { Sept } \\
2017\end{array}$ & $\begin{array}{l}27 \text { Sept } \\
2017\end{array}$ & $\begin{array}{l}28 \text { Sept } \\
2017\end{array}$ \\
\hline $\begin{array}{l}\text { Stamet Budiarto } \\
\text { Curug }\end{array}$ & 81.5 & 95 & 1 \\
\hline $\begin{array}{c}\text { Stamet Soekarno } \\
\text { Hatta }\end{array}$ & 0 & 86 & 16 \\
\hline $\begin{array}{c}\text { Balai Besar Wilayah II } \\
\text { Ciputat }\end{array}$ & 0 & 85 & 15 \\
\hline $\begin{array}{c}\text { Stasiun Geofisika } \\
\text { Tangerang }\end{array}$ & 4 & 76 & 7 \\
\hline Stamet Kemayoran & 0 & 71 & 27 \\
\hline ARG Mauk Tangerang & 5 & 64 & 7 \\
\hline ARG Kedoya & 0 & 53 & 9 \\
\hline ARG Lebak Bulus & 8 & 50 & 36 \\
\hline ARG Tomang & 8 & 47 & 11 \\
\hline $\begin{array}{c}\text { Stamet Pondok } \\
\text { Betung } \\
\end{array}$ & 8.5 & 33 & 17 \\
\hline Pos Hujan Pulomas & 0 & 38 & 90 \\
\hline $\begin{array}{c}\text { Pos Hujan } \\
\text { Pakubuwono }\end{array}$ & 0 & 34 & 12 \\
\hline Pos Hujan Manggarai & 0 & 27 & 16 \\
\hline $\begin{array}{c}\text { Pos Hujan Pasar } \\
\text { Minggu }\end{array}$ & 0 & 25 & 12 \\
\hline $\begin{array}{l}\text { Stamet Maritim } \\
\text { Tanjung Priok }\end{array}$ & 0 & 17 & 43 \\
\hline ARG Kelapa Gading & 0 & 6 & 35 \\
\hline Pos Hujan Halim PK & 0 & 2 & 11 \\
\hline
\end{tabular}


Distribusi spasial dari akumulasi curah hujan harian di wilayah DKI Jakarta pada periode waktu kejadian disajikan dalam bentuk isohyet, dimana isohyet adalah garis yang menghubungkan tempat-tempat yang mempunyai tinggi hujan yang sama. Secara lengkap ditampilkan pada gambar-gambar berikut ini :

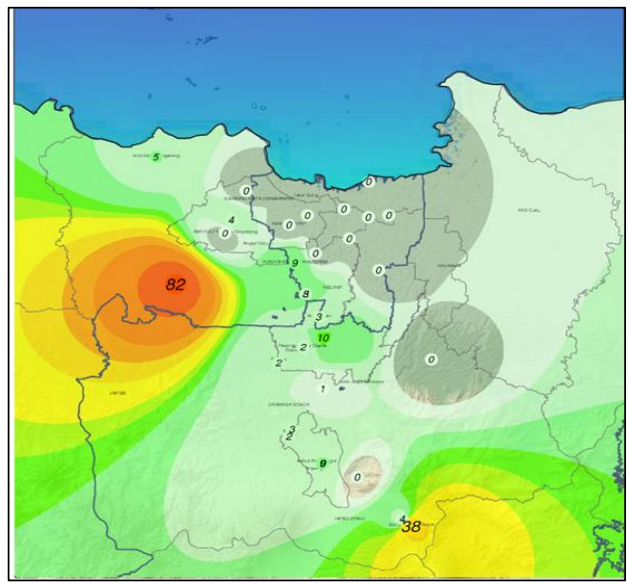

Gambar 2. Isohyet tanggal 26 September 2017 di wilayah Jabodetabek.

Berdasarkan gambar 2, pada tanggal 26 September 2017, curah hujan dengan intensitas ringan hingga lebat terjadi di sebagian Jakarta Selatan, Kota Tangerang, Kabupaten Tangerang, Kabupaten Bogor dan Kota Bogor, dengan curah hujan tertinggi sebesar $82 \mathrm{~mm}$ di Stasiun Budiarto Curug, Tangerang.

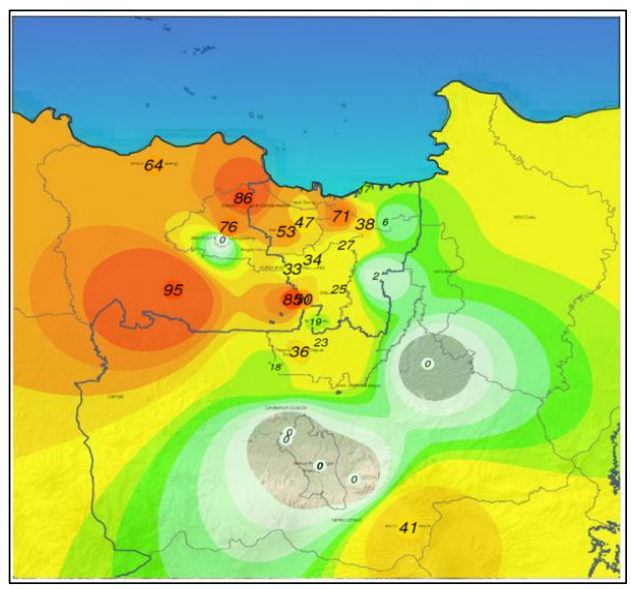

Gambar 3. Isohyet tanggal 27 September 2017 di wilayah Jabodetabek.

Berdasarkan gambar 3 terlihat bahwa hujan yang terjadi pada tanggal 27 September 2017 cukup merata distribusinya di wilayah Jabodetabek, dengan intensitas maksimum di wilayah Tangerang, Jakarta Barat, Jakarta Pusat, dan Jakarta Selatan. Curah hujan tertinggi tercatat terjadi di Stasiun Meteorologi Curug, Tangerang, sebesar $95 \mathrm{~mm} /$ hari. Sedangkan di wilayah DKI Jakarta curah hujan tertinggi terjadi di wilayah Kemayoran, Jakarta Pusat, sebesar 71 $\mathrm{mm} / \mathrm{hari}$.

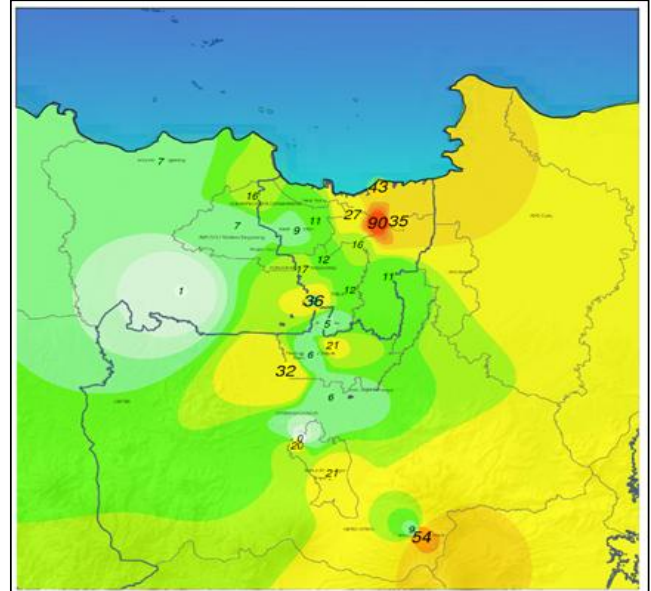

Gambar 4. Isohyet tanggal 28 September 2017 di wilayah Jabodetabek.

Curah hujan di tanggal 28 September (Gambar 4) juga masih nampak cukup signifikan dengan kisaran intensitas ringan hingga lebat, terutama di wilayah Jakarta Utara, Jakarta Pusat dan Jakarta Timur bagian utara, meski secara rata-rata tidak setinggi curah hujan pada hari sebelumnya. Curah hujan harian tertinggi tercatat sebesar $90 \mathrm{~mm}$ di pos hujan kerjasama Pulomas, Jakarta Timur.

\subsection{Analisis Dinamika Atmosfer}

\subsubsection{SOI}

Indeks SOI bernilai +4.1 , tidak signifikan karena dibawah nilai ambangnya yaitu +7 , hal ini mengindikasikan bahwa suplai uap air dari Samudera Pasifik Timur ke Pasifik Barat tidak signifikan atau aktivitas potensi pembentukan awan hujan, terutama di wilayah Indonesia Timur kurang signifikan.

\subsubsection{Indeks ENSO}

ENSO berpengaruh terhadap kekeringan akibat musim kemarau yang lebih lama dari biasanya (Aldrian, 2002). Sejak tahun 1844, Indonesia telah mengalami kejadian kekeringan tidak kurang dari 43 kali. Dari 43 kejadian tersebut, hanya 6 kali yang kejadiannya tidak bersamaan kejadian fenomena ENSO, hal ini menunjukkan, bahwa keragaman hujan di Indonesia sangat dipengaruhi oleh fenomena ini (Boer, 2003).

Dari bulan Juni sampai November, ada hubungan yang signifikan dari pola curah hujan dengan ENSO di kawasan A (Indonesia bagian Selatan dari Sumatera Selatan sampai pulau Timor, Kalimantan bagian selatan, Sulawesi dan sebagian dari Papua). Pengaruh ENSO yang kuat selama musim kering (Juni sampai September) berbahaya pada tahun-tahun ElNino, karena SST yang lebih tinggi di NIÑO 3 wilayah Pasifik akan menurunkan jumlah curah hujan di wilayah Indonesia (Aldrian \& Susanto, 2003). 
Sementara itu nilai indeks ENSO di Nino 3.4 bernilai $(-0.28)$ yang masih masuk dalam kategori normal yaitu \pm 0.5 , sehingga pengaruhnya tidak signifikan terhadap hujan harian di wilayah Indonesia.

\subsection{3. $M J O$}

Fase MJO hingga tanggal 27 September 2017 berada di kuadran 7 (Gambar 5), Samudera Pasifik Barat, dalam fase netral, yang mengindikasikan bahwa tidak ada kontribusi terhadap pembentukan awan di wilayah Indonesia, termasuk di DKI Jakarta dan sekitarnya.

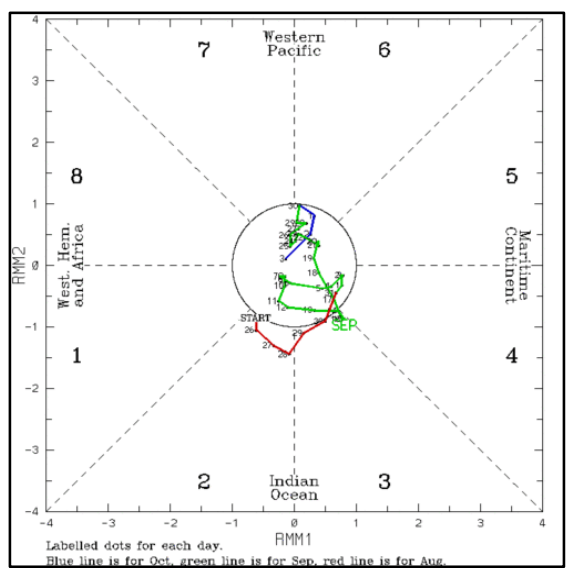

Gambar 5. Diagram fase MJO. Garis hijau menggambarkan fase MJO di bulan September.

(Sumber : www.bom.gov.au)

\subsubsection{IOD}

Nilai indeks IOD atau biasa dikenal dengan DMI bernilai +0.02 (Gambar 6), dimana masih tergolong lemah, jika dibandingkan dengan nilai ambangnya yaitu \pm 0.4 . Hal ini berarti suplai uap air dari wilayah Samudera Hindia ke wilayah Indonesia bagian Barat tidak signifikan atau aktivitas pembentukan awan di wilayah Indonesia bagian Barat tidak signifikan.

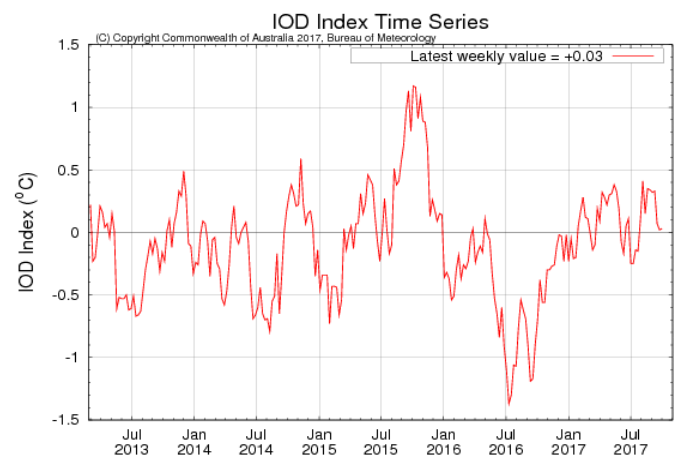

Gambar 6. Grafik indeks IOD bulan Januari 2013 s.d. Oktober 2017. (Sumber : www.bom.gov.au)

\subsubsection{Seruakan Dingin}

Seruakan dingin atau yang lebih dikenal dengan istilah cold surge memiliki indeks dengan nilai +1.9, yang masih tergolong lemah dibandingkan nilai ambangnya yaitu $>+10$. Hal ini mengindikasikan bahwa aliran massa udara dingin ke wilayah Indonesia bagian barat tidak signifikan.

\subsubsection{Analisis Medan Angin}

Daerah shearline dan konvergensi yang menandakan daerah potensi pertumbuhan awan hujan terdapat di wilayah Aceh, Sumatera Utara, Sumatera Barat, Sumatera Selatan, Bengkulu, Lampung, Banten, Kalimantan Tengah, Kalimantan Barat, Maluku Utara, dan Papua Barat.

Berdasarkan analisis angin gradien lapisan $3000 \mathrm{ft}$ pada tanggal 26 September 2017 jam 19.00 LT (Gambar 7), terlihat adanya pusaran angin lemah (eddy) di sekitar Selat Karimata dan di Samudera Hindia sebelah barat Aceh sehingga membentuk daerah pertemuan dan perlambatan massa udara angin yang melewati wilayah Jabodetabek, kondisi ini mendukung pertumbuhan awan konvektif di wilayah Jabodetabek.

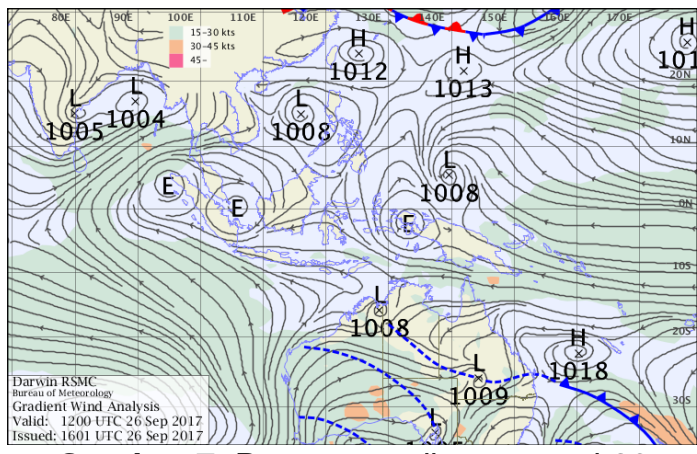

Gambar 7. Peta streamline tanggal 26

September 2017 jam 12 UTC. (Sumber : www.bom.gov.au)

Berdasarkan gambar 8, angin pada lapisan 850 hpa di wilayah DKI Jakarta bertiup dari arah Barat Laut - Utara dengan kecepatan berkisar antara 5-15 knot. Terlihat pula adanya daerah konvergensi di Banten, DKI Jakarta hingga Jawa Barat. Daerah belokan angin terbentuk di Samudera Hindia selatan Jawa bagian barat.

Jika dibandingkan dengan normal pola angin selama 30 tahun terakhir (Gambar 9), maka terlihat bahwa pola angin pada saat kejadian merupakan anomali, dimana berdasarkan klimatologinya arah angin dominan adalah Timur-Tenggara, namun pada 27 September lalu arah angin dominan adalah Barat Laut - Utara.

Pada musim basah angin zonal baratan dan angin meridional menuju selatan dominan terjadi di Indonesia. Sedangkan saat musim kering angin zonal timuran dan angin dari selatan menuju utara mendominasi wilayah Indonesia (Visa et al., 2012). Mulyana (2015) juga menyatakan selama kegiatan penanggulangan banjir di wilayah Jakarta Tahun 2014 angin baratan mendominasi wilayah Jakarta dan sekitarnya. 


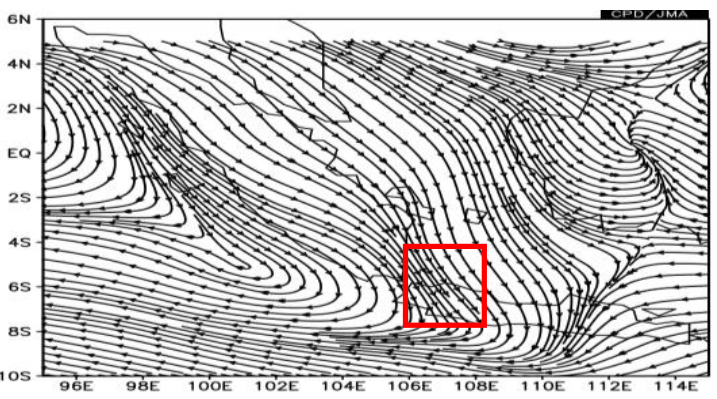

Gambar 8. Medan angin lapisan $850 \mathrm{hPa}$ tanggal 27 September 2017 Jam 00 UTC. (Kotak merah adalah wilayah DKI Jakarta)

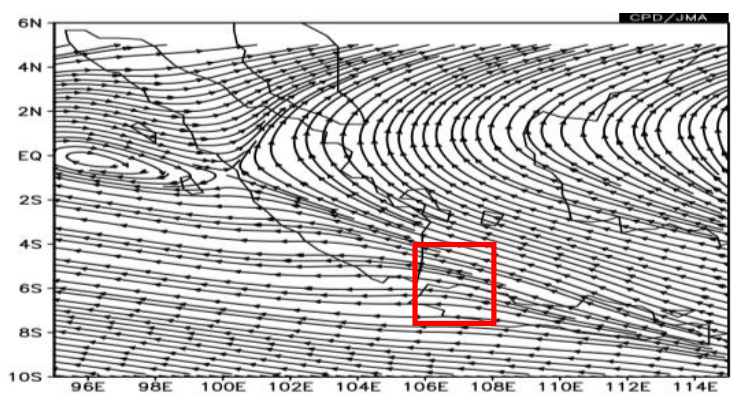

Gambar 9. Klimatologis medan angin lapisan $850 \mathrm{hPa}$ tanggal 27 September, periode tahun $1981-2010$.

Pola angin di lapisan $700 \mathrm{hPa}$ masih sama seperti pola angin di lapisan $850 \mathrm{hPa}$, daerah shearline masih terbentuk di Jawa Barat bagian Tengah. Angin dominan dari Barat Laut - Utara dengan kecepatan 5-15 knot (Gambar 10).

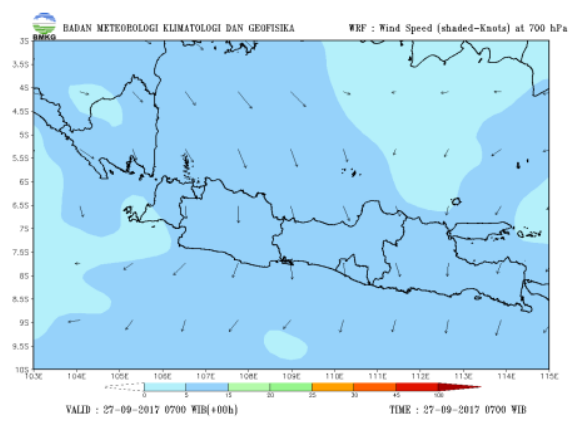

Gambar 10. Medan angin lapisan $700 \mathrm{hPa}$ tanggal 27 September 2017 Jam 00 UTC.

Pola angin di lapisan $500 \mathrm{hPa}$ bervariasi dari arah Timur Laut - Timur dengan kecepatan 5-15 knot (Gambar 11).

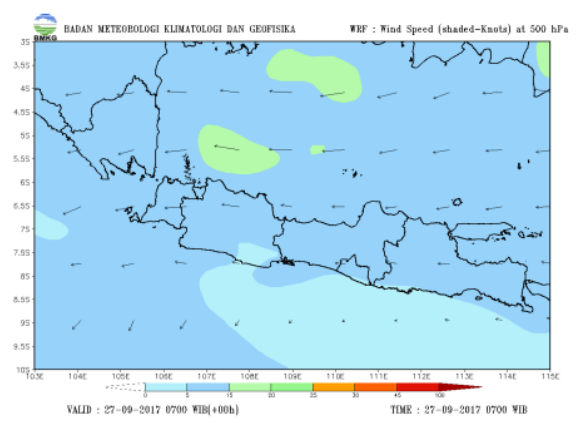

Gambar 11. Medan angin lapisan $500 \mathrm{hPa}$ tanggal 27 September 2017 Jam 00 UTC.
Berdasarkan analisis angin zonal lapisan $850 \mathrm{hPa}$ seperti yang terlihat pada gambar 12 , anomali arah angin dominan dibandingkan klimatologisnya (Gambar 13). Dimana berdasarkan klimatologisnya, komponen angin yang dominan seharusnya angin timuran (bernilai negatif), namun pada 27 September lalu komponen angin yang dominan adalah baratan (bernilai positif).

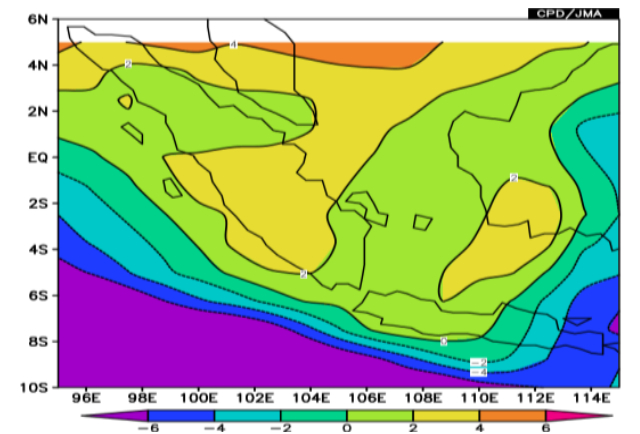

Gambar 12. Angin zonal lapisan $850 \mathrm{hPa}$ tanggal 27 September 2017.

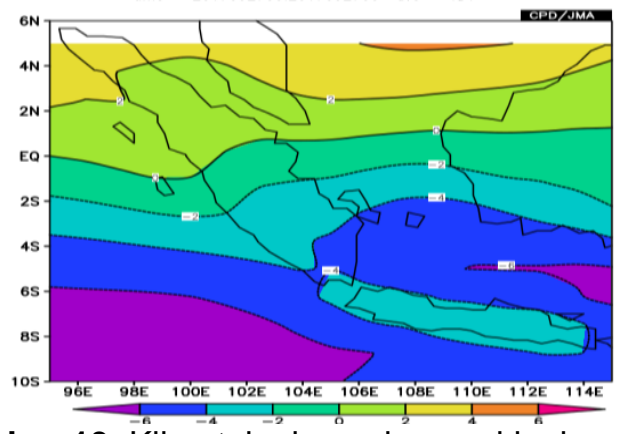

Gambar 13. Klimatologis angin zonal lapisan 850 $\mathrm{hPa}$ tanggal 27 September, periode tahun 19812010.

Dari hasil analisis komponen angin meridional pada tanggal 27 September 2017 lalu, teridentifikasi adanya anomali, dimana berdasarkan klimatologis selama 30 tahun terakhir komponen meridional yang dominan seharusnya adalah komponen selatan (bernilai positif), namun pada saat kejadian hujan lebat yang lalu komponen meridional yang dominan adalah komponen utara (bernilai negatif), hal ini bisa dilihat pada gambar 14 dan gambar 15 berikut.

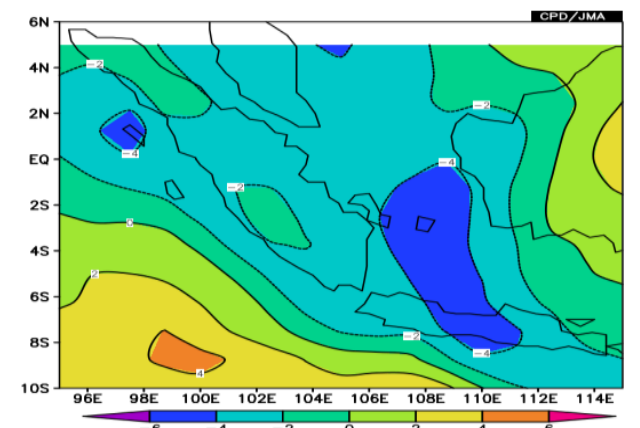

Gambar 14. Angin meridional lapisan $850 \mathrm{hPa}$ tanggal 27 September 2017. 


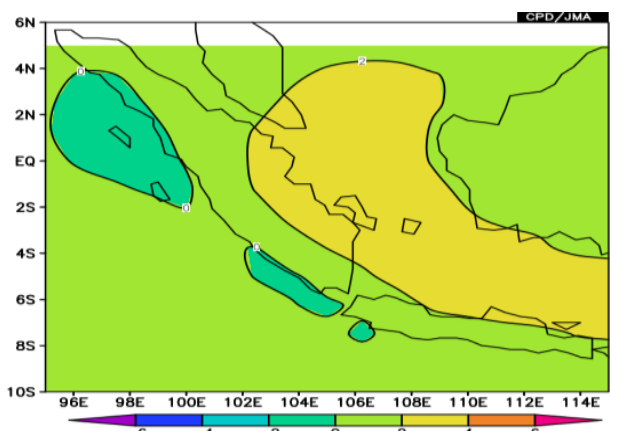

Gambar 15. Klimatologis angin meridional lapisan $850 \mathrm{hPa}$ tanggal 27 September, periode tahun 1981-2010.

\subsubsection{Analisis Suhu Muka Laut}

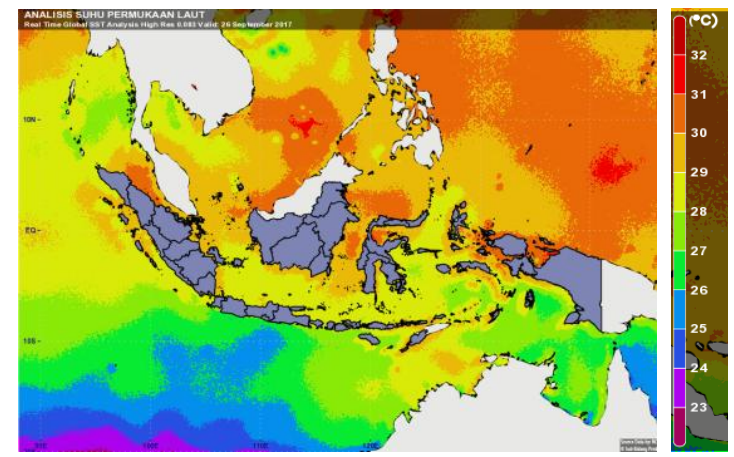

Gambar 16. Peta analisis SST (Suhu Muka Laut) tanggal 26 September 2017.

Berdasarkan gambar 16 , data model analisis peta Sea Surface Temperature (SST) tanggal 26 September 2017 menunjukkan suhu permukaan laut wilayah Jabodetabek bagian utara lebih hangat dibanding perairan Jawa Barat bagian selatan, yaitu berkisar $28-29^{\circ} \mathrm{C}$ dengan anomali berkisar $-0.5 \mathrm{~s} / \mathrm{d} 0.5^{\circ} \mathrm{C}$, mengindikasikan potensi penguapan dan penambahan massa uap air yang tinggi sehingga mendukung pertumbuhan awan hujan di wilayah Jawa.

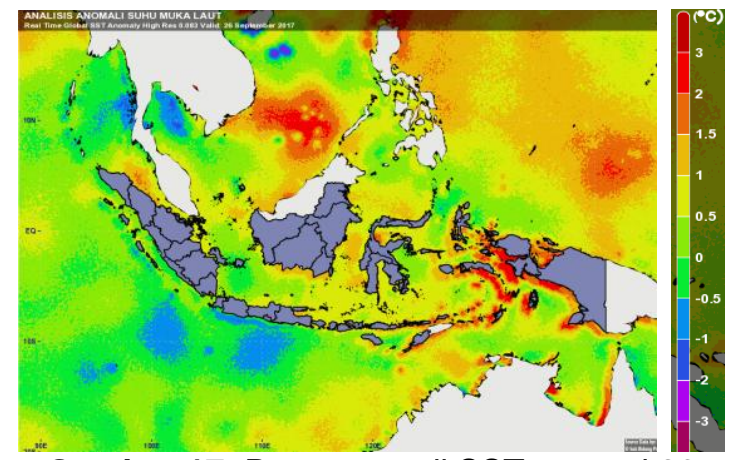

Gambar 17. Peta anomali SST tanggal 26 September 2017.

Nilai anomali SST di wilayah Indonesia berkisar antara $+1 \mathrm{~s} / \mathrm{d}+3.0{ }^{\circ} \mathrm{C}$ (Gambar 17). Potensi penguapan atau penambahan massa uap air di Selat Malaka, Selat Karimata bagian utara, Laut Andaman, Laut Jawa bagian timur, Laut Natuna, Samudera Hindia sebelah selatan NTT, Laut Flores, Laut Sawu, Laut Seram, Laut
Halmahera, Samudera Pasifik sebelah utara Papua, Teluk Cendrawasih, Selat Makassar dan Laut Sulawesi.

\subsubsection{Analisis Kelembapan Udara}

Kelembapan udara di lapisan $850 \mathrm{hPa}$ berkisar antara $80-90 \%$, yang menandakan kondisi atmosfer lembap dan mendukung pertumbuhan awan hujan. Kondisi ini merupakan anomali jika dibandingkan dengan kondisi klimatologisnya yang hanya bernilai antara 6070\%, yang ditampilkan pada Gambar 18 dan 19 berikut.

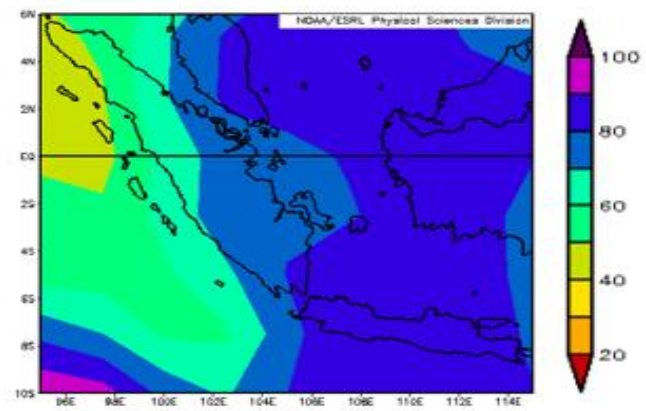

Gambar 18. Kelembapan udara lapisan $850 \mathrm{hPa}$ tanggal 27 September 2017.

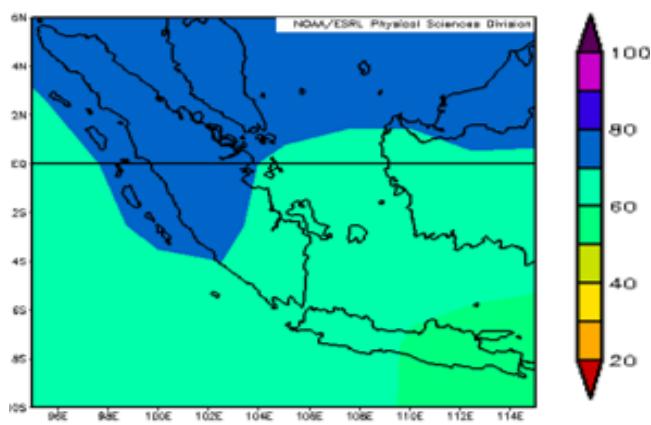

Gambar 19. Klimatologis kelembapan udara lapisan $850 \mathrm{hPa}$ tanggal 27 September, periode tahun 1981-2010.

Kelembapan udara di lapisan $700 \mathrm{hPa}$ berkisar antara $90-100 \%$, yang menandakan kondisi atmosfer lembab dan mendukung pertumbuhan awan konvektif. Kondisi ini sangat kontras dengan klimatologisnya yang berkisar antara $40-50 \%$, seperti ditampilkan pada Gambar 20 dan 21 berikut.

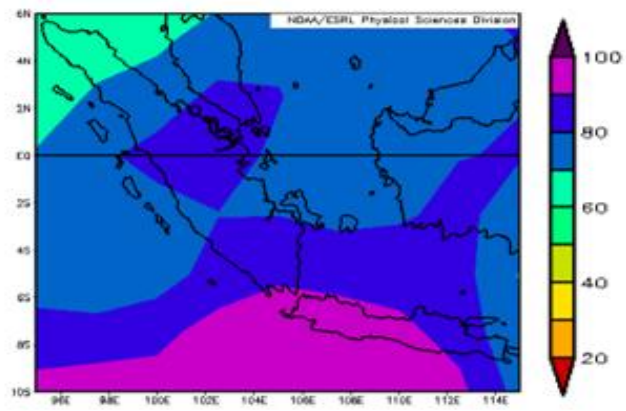

Gambar 20. Kelembapan udara lapisan $700 \mathrm{hPa}$ tanggal 27 September 2017. 


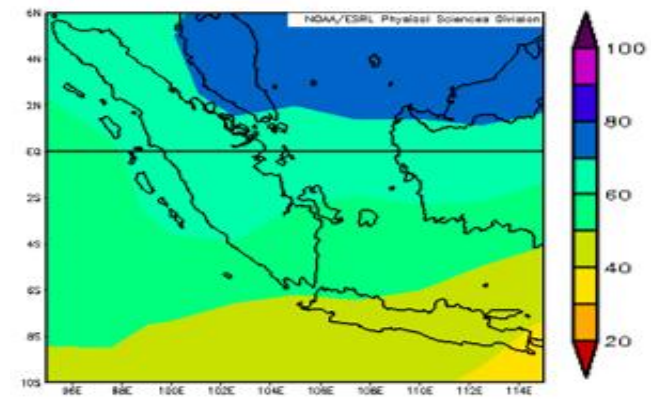

Gambar 21. Klimatologis kelembapan udara lapisan $700 \mathrm{hPa}$ tanggal 27 September, periode tahun 1981-2010.

Kelembapan udara di lapisan $500 \mathrm{hPa}$ berkisar antara $70-80 \%$, yang menandakan kondisi atmosfer lembap dan mendukung pertumbuhan awan-awan konvektif yang menjulang hingga lapisan atmosfer menengah. Kondisi ini sangat basah jika dibandingkan dengan nilai secara klimatologisnya yang hanya berkisar antara 30-40\% (Gambar 22 dan 23).

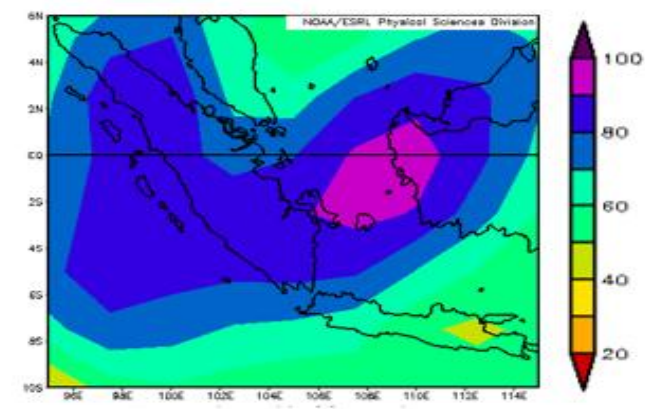

Gambar 22. Kelembapan udara lapisan 500 hPa tanggal 27 September 2017.

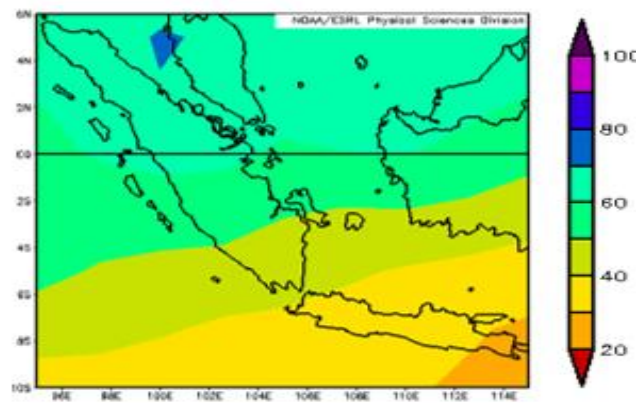

Gambar 23. Klimatologis kelembapan udara lapisan $500 \mathrm{hPa}$ tanggal 27 September, periode tahun 1981-2010.

\subsection{Analisis Citra Satelit Cuaca}

Berdasarkan citra satelit Himawari inframerah (Gambar 24 s/d 26), terlihat pertumbuhan awan konvektif di wilayah Tangerang bagian barat pada pukul 03.10 WIB yang meluas hingga seluruh wilayah Tangerang dan Tangerang Selatan pada 05.00 WIB. Awan konvektif pada citra Enhanced IR digambarkan dengan warna oranye hingga salem. Kondisi awan tersebut berlanjut meluas hingga ke seluruh wilayah Jakarta pada pukul 11.00 WIB hingga sore hari.
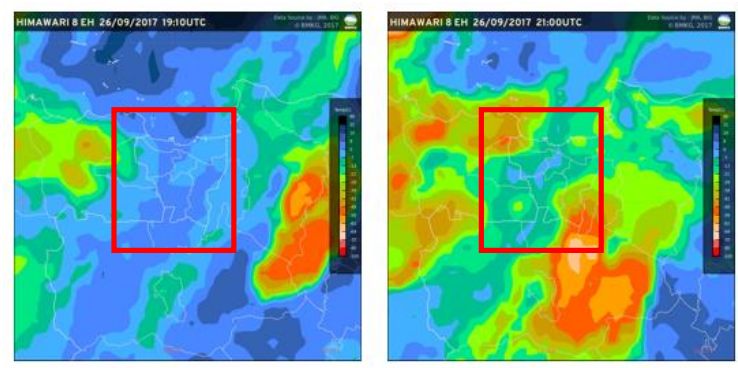

Gambar 24. Citra IR tanggal 27 September 2017 jam 02.00 \& 05.00 WIB. (Kotak merah adalah wilayah DKI Jakarta)
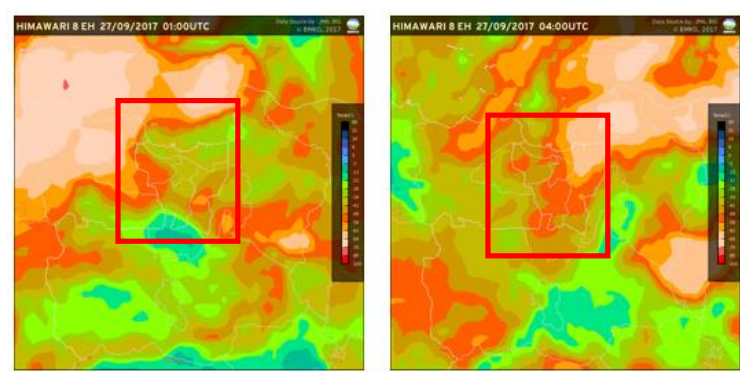

Gambar 25. Citra IR tanggal 27 September 2017 jam 08.00 \& 11.00 WIB.
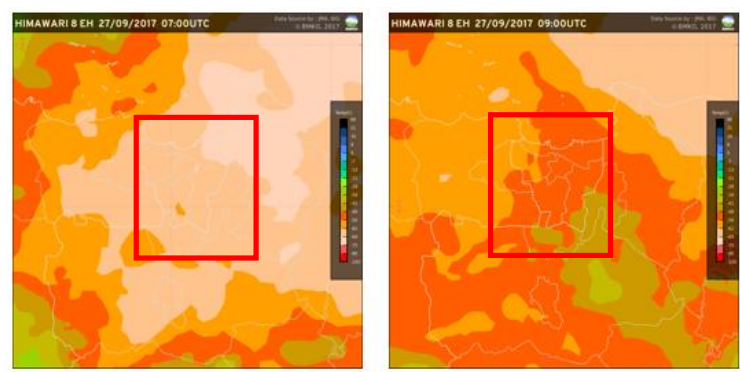

Gambar 26. Citra IR tanggal 27 September 2017 jam $14.00 \& 16.00$ WIB.

Berdasarkan citra klasifikasi awan dari HCAI (High-Resolution Cloud Analysis Information) (Gambar 27 s/d 29), Awan Cumulonimbus berada di wilayah Tangerang pada tanggal 27 September 2017 mulai pukul 05.00 WIB yang kemudian meluas di wilayah jakarta pada pukul 13.00 WIB hingga 16.00 WIB. Sedangkan Dense Cloud mendominasi wilayah Jabodetabek hampir sepanjang hari pada tanggal tersebut. Kedua jenis awan ini berpotensi menghasilkan hujan intensitas sedang hingga lebat.

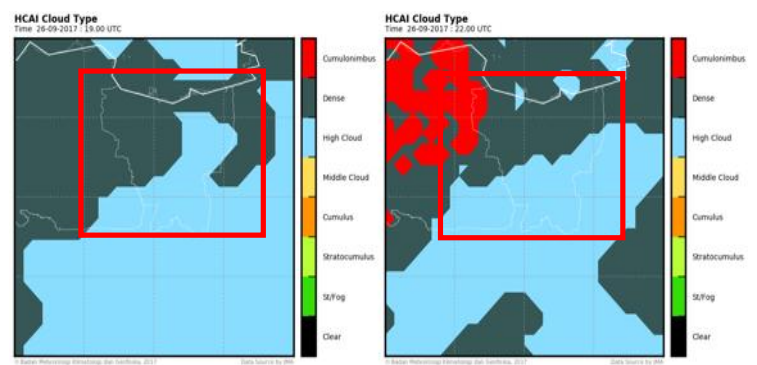

Gambar 27. Citra jenis awan tanggal 27

September 2017 jam 02.00 \& 05.00 WIB. (Kotak merah adalah wilayah DKI Jakarta) 


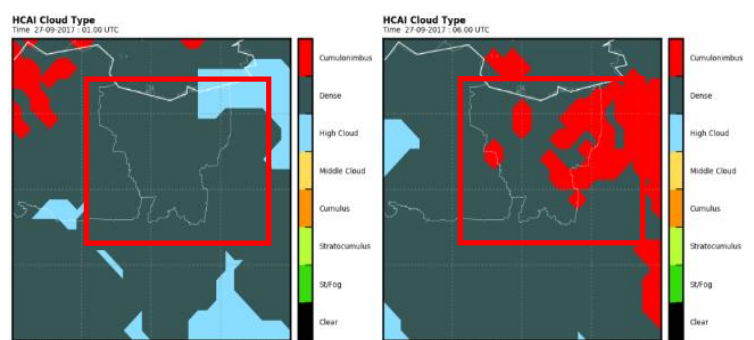

Gambar 28. Citra jenis awan tanggal 27 September 2017 jam $07.00 \& 13.00$ WIB.

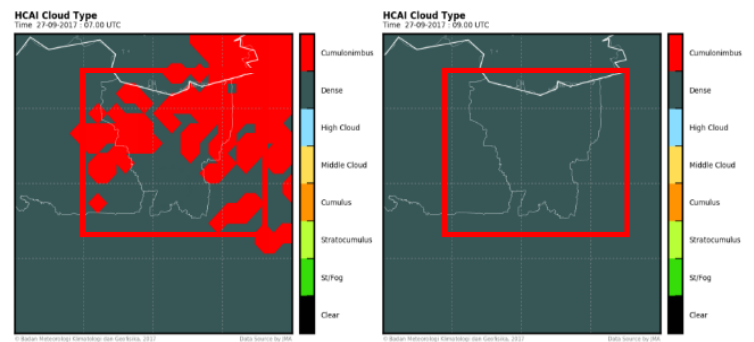

Gambar 29. Citra jenis awan tanggal 27 September 2017 jam 14.00 \& 16.00 WIB.

Berdasarkan grafik time series IR1 seperti yang terlihat pada Gambar 30, di lokasi sampel (Jakarta Pusat), penurunan suhu puncak awan (< $-60 \circ \mathrm{C})$ mulai terjadi pada pukul 13.00 WIB hingga 15.00 WIB yang menandakan terjadinya peningkatan proses konvektif signifikan dengan potensi hujan intensitas sedang hingga lebat pada periode tersebut.

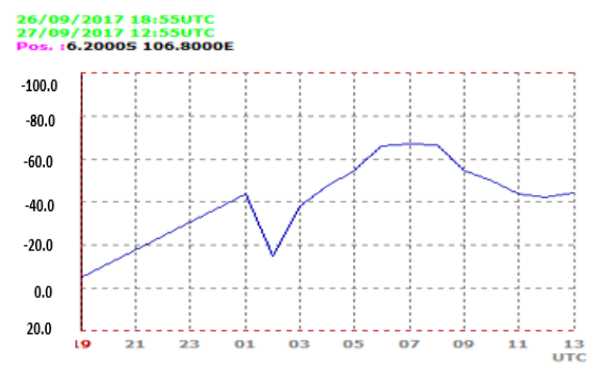

Gambar 30. Grafik suhu puncak awan tanggal 27 September 2017 pukul 01.00 s/d 20.00 WIB.

\subsection{Analisis Citra Radar Cuaca}

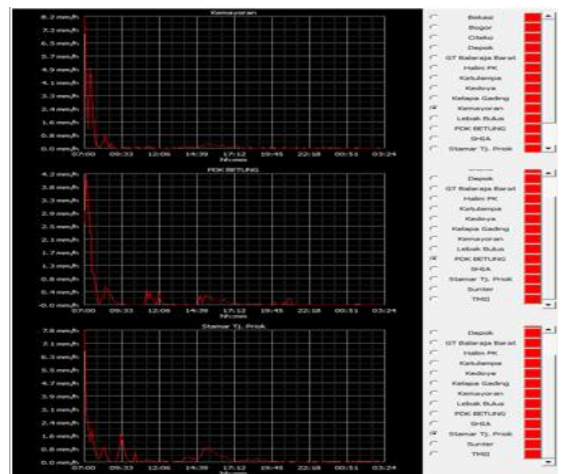

Gambar 31. Produk Rain Histograph tanggal 27 September 2017 jam 00-24 UTC di Stamet Kemayoran (atas), Staklim Pondok Betung (tengah) dan Stamar Tj. Priok (bawah).

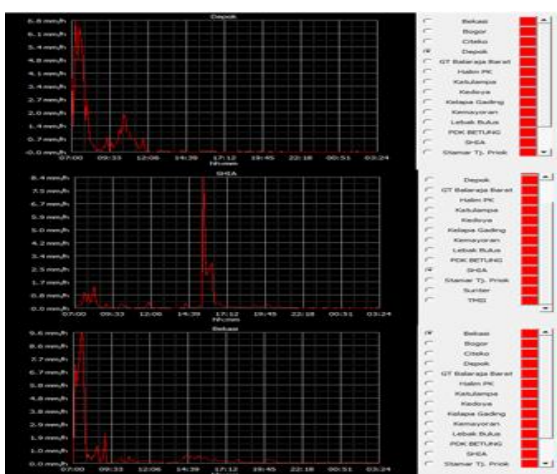

Gambar 32. Produk Rain Histograph tanggal 27 September 2017 jam 00-24 UTC di Depok (atas), Soekarno-Hatta (tengah) dan Bekasi (bawah).

Berdasarkan produk radar cuaca Rain Histograph (Gambar 31 dan 32), terlihat pada tanggal 27 September 2017 terjadi hujan dengan intensitas ringan hingga lebat dengan durasi yang cukup lama ( $\pm 12 \mathrm{Jam})$, hujan terjadi sejak dini hari hingga malam hari, curah hujan berkisar antara 0,5 s/d 20,0 mm yang merata di wilayah Jabodetabek.

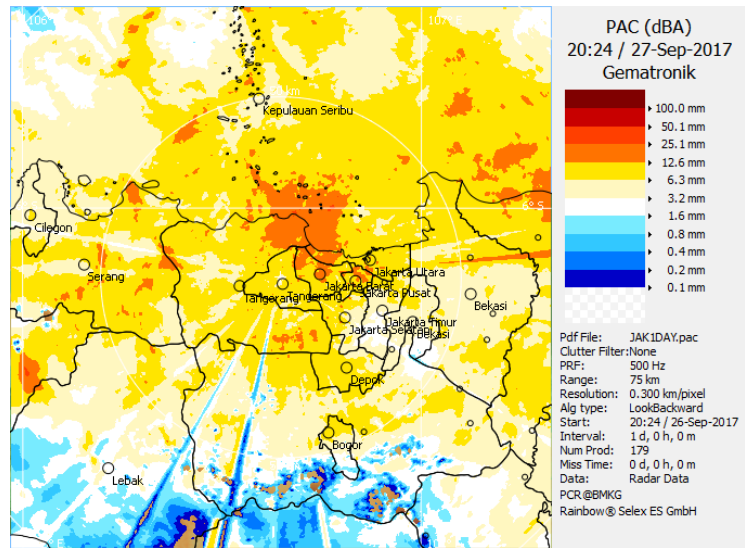

Gambar 33. Produk radar cuaca PAC tanggal 27 September 2017 jam 00-24 UTC.

Berdasarkan produk radar cuaca $P A C$ terlihat hujan terjadi secara merata di wilayah Jabodetabek, Curah hujan maksimum terjadi di wilayah Tangerang Selatan, Jakarta Utara dan Bekasi bagian Utara (Gambar 33).

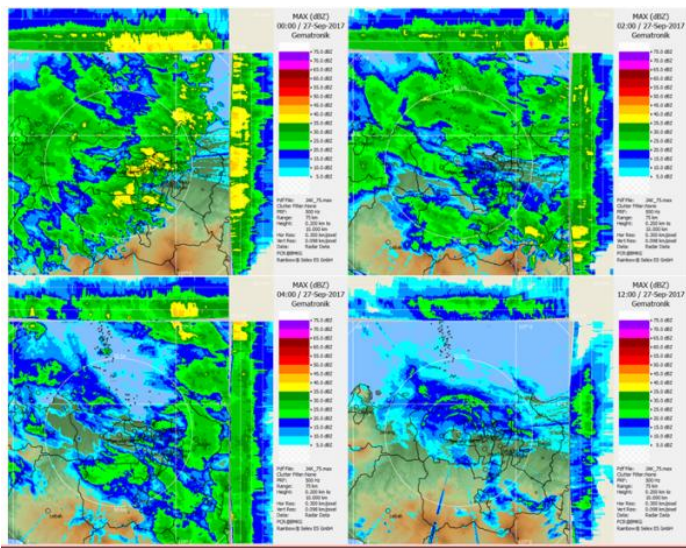

Gambar 34. Produk CMAX tanggal 27

September 2017 jam 00, 02, 04 dan 12 UTC. 
Berdasarkan produk radar cuaca CMAX (Gambar 34), terlihat pertumbuhan awan konvektif terjadi di wilayah Tangerang Selatan yang kemudian mulai berkembang dan bergerak menuju arah Timur hingga Tenggara memasuki wilayah DKI Jakarta. Reflektivitas berkisar antara $10 \mathrm{~s} / \mathrm{d} 45 \mathrm{dBz}$ yang mengindikasikan hujan intensitas ringan hingga lebat.

\section{KESIMPULAN}

Berdasarkan pembahasan diatas penulis mengambil beberapa kesimpulan mengenai kejadian hujan lebat yang memicu genangan di wilayah DKI Jakarta pada tanggal 27 September lalu sebagai berikut :

1. Berdasarkan analisis kondisi meteorologisnya, kejadian hujan lebat di wilayah DKI Jakarta dan sekitarnya pada tanggal 27 September 2017 lalu diakibatkan oleh pertumbuhan awan hujan tipe Nimbustratus dan Cumulonimbus yang signifikan, kondisi ini dipicu oleh adanya daerah pertemuan angin disertai perlambatan kecepatan angin dan atmosfer yang lembap hingga lapisan menengah,

2. Berdasarkan analisis citra satelit cuaca, dapat disimpulkan bahwa kondisi cuaca di wilayah Jabodetabek pada tanggal 27 September 2017 dari dini hari hingga sore hari diakibatkan oleh awan rendah dan awan konvektif yang menghasilkan hujan dengan intensitas sedang-lebat.

3. Berdasarkan analisis produk radar cuaca, dapat disimpulkan bahwa hujan terjadi secara merata di wilayah Jabodetabek dengan intensitas ringan hingga lebat, dengan durasi yang cukup lama yakni kurang lebih 12 jam.

\section{DAFTAR PUSTAKA}

Aldrian, E. (2002). Spatial Patterns of Enso Impact on Indonesian Rainfall. Jurnal Sains \& Teknologi Modifikasi Cuaca, 3(1), 5-15.

Aldrian, E. (2006). Decreasing Trends in Annual Rainfalls over Indonesia: A Threat for the National Water Resource. Jurnal Meteorologi dan Geofisika, 7(2), 40-49.

Aldrian, E. (2008). Dominant Factors of Jakarta's Three Largest Floods. Jurnal Hidrosfir Indonesia, 3(3), 105-112.

Aldrian, E., Susanto, R.D. (2003). Identification of Three Dominant Rainfall Regions within
Indonesia and Their Relationship to Sea Surface Temperature. International Journal of Climatology, 23(12), 1435-1452. doi: 10.1002/joc.950

Boer, R. (2003). Penyimpangan Iklim di Indonesia. Makalah Seminar Nasional IImu Tanah. KMIT Jurusan Tanah Fakultas Pertanian UGM. Yogyakarta.

BPBD. (2013). Rencana Penanggulangan Bencana Provinsi DKI Jakarta 2013-2017. (http://bpbd.jakarta.go.id.)

Gernowo, R., Yulianto, T. (2010). Fenomena Perubahan Iklim dan Karakteristik Curah Hujan Ekstrim di DKI Jakarta. Prosiding Pertemuan IImiah XXIV HFI Jateng \& DIY, 13-18.

Mulyana, E. (2015). Analisis Cuaca pada saat Pelaksanaan TMC Penanggulangan Banjir Jakarta Januari Februari 2014. Jurnal Sains \& Teknologi Modifikasi Cuaca, 16(1), 15-20.

Prabawadhani, D,R., Harsoyo, B., Seto, T.H., Prayoga, M.B.R. (2016). Karakteristik Temporal dan Spasial Curah Hujan Penyebab Banjir di Wilayah DKI Jakarta dan Sekitarnya. Jurnal Sains \& Teknologi Modifikasi Cuaca, 17(1), 21-25.

Renggono, F., Hashiguchi, H., Fukao, S., Yamanaka, M.D., Ogino, S.Y., Okamoto, N., Murata, F., Sitorus, B.P., Kudsy, M., Kartasasmita, M., Ibrahim, G. (2001). Precipitating Clouds Observed by 1.3-GHz Boundary Layer Radars in Equatorial Indonesia. Annales Geophysicae, 19, 889897.

Siswanto., van der Schrier, G., van Oldenborgh, G.J., van den Hurk, B., Aldrian, A., Swarinoto, Y., Sulistya, W., Sakya, A.E. (2017). A Very Unusual Precipitation Event Associated with the 2015 Floods in Jakarta: An Analysis of the Meteorological Factors. Weather and Climate Extremes, 16, 23-28. doi: 10.1016/j.wace.2017.03.003.

Utomo, D. (2012). Proyeksi Hujan Ekstrem untuk Analisis Potensi Banjir di DKI Jakarta. Skripsi. Fakultas Ilmu dan Teknologi Kebumian, Institut Teknologi Bandung.

Visa, J., Marpaung, S., Adikusumah, N. (2012). Karakteristik Angin Zonal dan Meridional pada Saat Musim Basah dan Kering di Wilayah Indonesia. Penelitian Masalah Lingkungan di Indonesia 2012, 27-35. 